Bangladesh J. Plant Taxon. 27(1): 15-26, 2020 (June)

(C) 2020 Bangladesh Association of Plant Taxonomists

\title{
A COMPARATIVE ANATOMICAL INVESTIGATION OF THREE TAXA OF BRASSICA L. FROM BANGLADESH
}

\author{
Faria Akbar and Kazi Nahida Begum* \\ Department of Botany, Faculty of Life and Earth Sciences, Jagannath University, \\ Dhaka-1100, Bangladesh
}

Key words: Brassica L.; Root anatomy; Stem anatomy; Stomata; Trichome.

\begin{abstract}
In the present study, micromorphology and comparative anatomy of young root, stem and leaf of three economically important taxa of Brassica L. viz., B. rapa L. subsp. campestris (L.) Clapham, B. juncea (L.) Czern. and B. napus L. are investigated in detail for the first time in Bangladesh by using light microscopy (LM). In anatomical studies, cross sections of young root, stem and leaf have been examined and biometric measurement of cell and tissues are presented. The micromorphological studies are related to the epidermal surface. In addition, the stomatal index and stomatal index ratio of these taxa have been calculated and presence of simple, non-glandular, unicellular trichome on stems and leaves also been observed except on the stem of B. rapa L. subsp. campestris (L.) Clapham. The anatomical study reveals that the investigated taxa have primary growth in roots and stems as well as amphistomatic and bifacial leaves with anisocytic stomata have been noticed. Finally, presence of tetrarch or single strand exarch xylem in vascular bundle of root, the size, shape and presence or absence of trichome over stem, shape of midrib of leaf have been considered to provide reliable features for identification of the Brassica species.
\end{abstract}

\section{Introduction}

The family Brassicaceae consists of 338 genera and 3709 species and dispersed all through the world, basically in temperate regions of the Northern Hemisphere (Warwick et al., 2006; Kasem et al., 2011). Among the genera, the genus Brassica L. includes around 100 economically important species with great hereditary and morphological assorted diversity (Jahan et al., 2013). The principal distribution centers of the family are the Mediterranean, Irano-Turanian and SaharoSindian regions (Hedge, 1976). In Bangladesh, the Brassicaceae family is represented by 12 genera and 24 species (Ahmed et al., 2008).

The genus is noteworthy for containing more important agricultural and horticultural crops like oilseed, vegetables, medicine and condiments than any other genus (Saha et al., 2008). Oleiferous Brassica species viz. B. rapa, B. juncea and B. napus constitute the world's third most vital source of consumable oils (Gupta and Pratap, 2007), and are considered as one of the leading oilseed crops in Bangladesh (Razzaque and Karim, 2007).

Metcalfe and Chalk (1957) studied the anatomy of Cruciferae and destined the diagnostic anatomical characteristics including epidermal cell type, stomata type and the array of the sclerenchymatic cells around the vascular bundles of the leaves. The quantity of morphological and taxonomic studies in Cruciferae has expanded in recent years (Khatun et al., 2011; Kaya and Dirmenci, 2012; Bayirli et al., 2014; Selvi et al., 2014; Hayta et al., 2014; Satil et al., 2015).

*Corresponding author, email: kazinahida@yahoo.com 
No micromorphological and anatomical study on the available and economically important species of Brassica L. from Bangladesh has been conducted so far. Therefore, the purpose of this paper is to investigate the anatomical and micromorphological properties of three important taxa of the genus Brassica.

\section{Materials and Methods}

Plant materials

Three species of Brassica L. namely, B. rapa L. subsp. campestris (L.) Clapham, B. juncea (L.) Czern. and B. napus L. were chosen for this study because of their availability and economic importance (Fig. 1). Among the three Brassica L. species, the seeds of B. rapa L. subsp. campestris (L.) Clapham were collected from Bangladesh Institute of Nuclear Agriculture (BINA), Mymensingh, Bangladesh. Seeds of B. juncea (L.) Czern. and B. napus L. were collected from the Oilseeds Research Center (ORC) of Bangladesh Agricultural Research Institute (BARI), Joydebpur, Gazipur, Bangladesh. These three species were maintained in the Botanical garden, Department of Botany, Jagannath University, Dhaka.
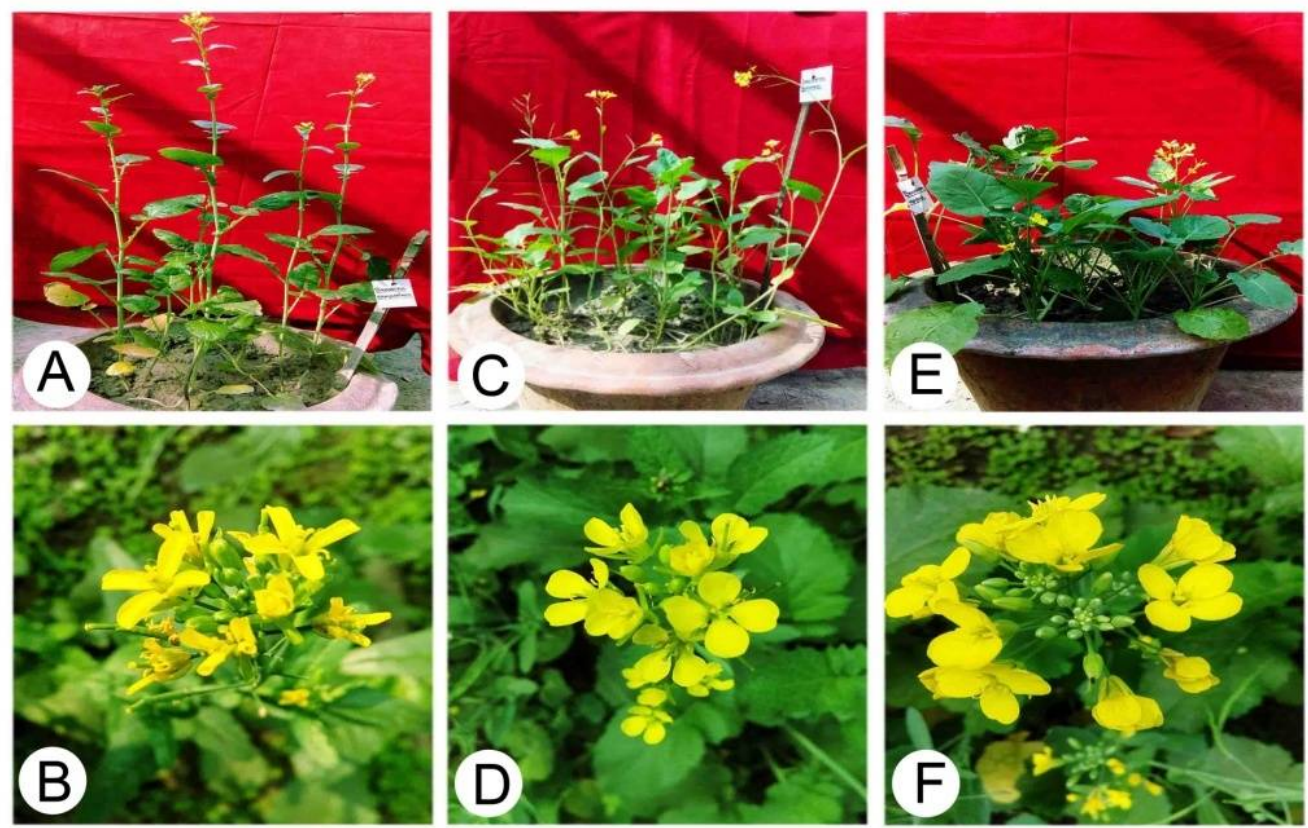

Fig. 1. Habit of three species of Brassica L. A-B. B. rapa subsp. campestris; C-D. B. juncea; E-F. B. napus; A, C, E: Plant morphology; B, D, F: Flowers.

\section{Anatomical investigation}

Fresh specimens were collected for the study of the internal structures of the studied species of Brassica. Transverse section of the vegetative organs, viz. young root, stem and leaf were chosen as they might provide discrete anatomical features of taxonomic importance. Free hand sectioning of young root, stem and leaf was made with the help of a razor blade. The sections were stained with safranin $(0.1 \%)$ for $15 \mathrm{~min}$. After that the well stained section were mounted in $20 \%$ glycerin (Shethi et al., 2017) and selected sections were prepared for permanent slides. 
Stomatal density on abaxial and adaxial surfaces of the leaf was counted under a light microscope. Stomatal index was calculated according to the method of Meidner and Mansfield (1968). Stomatal terminology and the leaf epidermal terminology were based on the classification provided by Dilcher (1974) and Wilkinson (1979), respectively. The trichomes were investigated on the both surface of leaves of all studied species and examined by light microscopy. Trichome description and classification followed Theobald et al. (1979). The permanent slides were studied under a compound light microscope Optica. Micrographs were captured from various regions of the sections using different magnifications through Euromex camera. Measurements of sections were made by using Image Focus 4 English software. Biometric measurements of anatomical characters were made by taking three times measurement of different cells and tissue of each species.

\section{Results and Discussion}

The comparative anatomy and micromorphology of Brassica species growing in Bangladesh are thoroughly investigated. The biometric measurements of the anatomical characteristics of $B$. rapa subsp. campestris, B. juncea and B. napus based on young root, stem and leaf are presented in Table 1. Comparative anatomical characters of young root, stem and leaf of the investigated species are given in Tables 2, 3 and 4, respectively. Leaf epidermal surface characters of the studied species of Brassica, examined micromorphologically, are shown in Table 5.

\section{Root anatomy}

In the cross-section of young root, the root exhibits a primary structure. There is epidermis which makes up the outermost layer of the root and consists of single layered, compactly packed, elongated barrel shaped cells, having no cuticle and stomata. The epidermal layer width is the lowest in $B$. rapa subsp. campestris $(51.37 \mu \mathrm{m})$, while it is highest in $B$. napus $(85.73 \mu \mathrm{m})$ (Table 1). On epidermal layer, root hairs are found to be present in $B$. rapa subsp. campestris and $B$. juncea but absent in $B$. napus. Immediately beneath the epidermis, there is cortex that consists of 4-9 thin-walled parenchyma cell layers, sometimes having intercellular spaces among them and cells are usually elliptical, circular and oval in shape. Below the cortex layer, a distinct endodermis layer is found, consisting of elliptical cells. The pericycle consists of thin walled parenchyma cells, found to be present as uniseriate which makes the outer boundary of the primary vascular bundle of the roots of examined species. The xylem forms four discrete strands- the tetrarch, alternating with the phloem in B. rapa subsp. campestris and B. napus while B. juncea exihibited with the xylem which is occupied the center. The xylem present in the vascular bundle of root in all the studied species are exarch. The phloem is located under the pericycle and is composed of 4-6 layered overlapping sequence of cells. The parenchymatous conjunctive tissues occur in between xylem and phloem strands. No cambium is observed in the examined species of Brassica L. Except in $B$. juncea the central part of the stele is occupied by well-developed pith which is found sclerenchymatous, while the pith is found inconspicuous or absent in B. juncea (Fig. 2 and Table 2).

\section{Stem anatomy}

In the transverse section of stem, a few variations reveal among the three different examined species of Brassica. The stems of studied species also exhibit primary structure. The contour of stem is round in $B$. juncea and ovoid in B. napus (Figs. 3C and 3E), while polygonal in B. rapa subsp. campestris (Fig. 3A). Margin of all the species have ridges and furrows. Except in B. rapa subsp. campestris, the other two species, viz. B. juncea and B. napus have sparsely situated trichomes on the outer surface of stem. B. juncea contains very few, small, non-glandular, 
Table 1. Biometric measurement of anatomical characters of three species of Brassica $\mathbf{L}$.

\begin{tabular}{|c|c|c|c|c|c|c|c|c|c|c|c|c|}
\hline \multirow{3}{*}{$\begin{array}{l}\text { Parameters } \\
\text { Root }\end{array}$} & \multicolumn{4}{|c|}{$\begin{array}{c}\text { Brassica rapa subsp. } \\
\text { campestris }\end{array}$} & \multicolumn{4}{|c|}{ Brassica juncea } & \multicolumn{4}{|c|}{ Brassica napus } \\
\hline & \multicolumn{2}{|c|}{ Length $(\mu \mathrm{m})$} & \multicolumn{2}{|c|}{ Width $(\mu \mathrm{m})$} & \multicolumn{2}{|c|}{ Length $(\mu \mathrm{m})$} & \multicolumn{2}{|c|}{ Width $(\mu \mathrm{m})$} & \multicolumn{2}{|c|}{ Length $(\mu \mathrm{m})$} & \multicolumn{2}{|c|}{ Width $(\mu \mathrm{m})$} \\
\hline & Mean & STD & Mean & STD & Mean & STD & Mean & STD & Mean & STD & Mean & STD \\
\hline Epidermal cells & 76.49 & 8.97 & 51.37 & 6.65 & 87.86 & 0.51 & 78.68 & 9.87 & 112 & 15.57 & 85.73 & 9.16 \\
\hline Root hair & 55.81 & 1.00 & - & - & 415.33 & 38.06 & - & - & - & - & - & - \\
\hline Cortex layers & - & - & 68.92 & 10.99 & - & - & 347.09 & 33.88 & - & - & 443.45 & 7.91 \\
\hline $\begin{array}{l}\text { Endodermal } \\
\text { cells }\end{array}$ & 21.60 & 2.87 & 11.30 & 2.72 & 60.14 & 16.17 & 50.24 & 13.58 & 73.82 & 6.77 & 62.21 & 8.29 \\
\hline Pericycle cells & 62.30 & 11.37 & 48.04 & 5.71 & 64.92 & 11.90 & 53.93 & 6.90 & 54.63 & 16.17 & 49.11 & 3.92 \\
\hline Phloem layers & - & - & 17.53 & 3.42 & - & - & 47.94 & 7.47 & - & - & 40.58 & 14.31 \\
\hline Tracheid cells & 7.94 & 1.02 & 6.43 & 0.60 & 40.47 & 4.25 & 36.77 & 1.92 & 38.46 & 3.97 & 31.77 & 10.38 \\
\hline \multicolumn{13}{|l|}{ Stem } \\
\hline Cuticle & - & - & 7.01 & 0.75 & - & - & 7.77 & 4.49 & - & - & 5.36 & 1.02 \\
\hline Epidermal cells & 36.22 & 2.77 & 29.45 & 1.64 & 32.10 & 5.36 & 23.76 & 7.95 & 23.75 & 10.37 & 16.15 & 3.77 \\
\hline Trichomes & - & - & - & - & 75.25 & 3.67 & - & - & 342.82 & 77.97 & - & - \\
\hline Cortex layers & - & - & 158.96 & 77.54 & - & - & 194.70 & 45.29 & - & - & 198.52 & 94.66 \\
\hline $\begin{array}{l}\text { Endodermal } \\
\text { cells }\end{array}$ & 29.16 & 6.17 & 19.37 & 2.66 & 72.84 & 15.16 & 51.58 & 9.42 & 32.84 & 8.85 & 27.13 & 3.52 \\
\hline Pericycle layer & - & - & 54.86 & 21.74 & - & - & 40.34 & 21.62 & - & - & 88.92 & 30.88 \\
\hline Phloem layers & - & - & 19.38 & 12.62 & - & - & 28.89 & 10.00 & - & - & 47.55 & 13.66 \\
\hline Cambium layer & - & - & - & - & - & - & 65.08 & 12.00 & - & - & 69.08 & 4.21 \\
\hline Tracheid cells & 27.03 & 4.74 & 23.79 & 4.58 & 12.68 & 1.49 & 11.56 & 1.70 & 24.40 & 2.47 & 20.67 & 1.19 \\
\hline Pith region & - & - & 963.89 & 18.12 & - & - & 694.15 & 16.46 & - & - & 1147.93 & 35.23 \\
\hline Pith cells & 77.42 & 47.90 & 73.88 & 49.16 & 85.12 & 28.45 & 65.08 & 12.00 & 67.10 & 36.09 & 48.47 & 35.16 \\
\hline \multicolumn{13}{|l|}{ Leaf } \\
\hline Cuticle & - & - & 3.38 & 1.38 & - & - & 3.06 & 1.16 & - & - & 3.40 & 0.65 \\
\hline Trichome & 81.75 & 99.30 & - & - & 510.32 & 34.97 & - & - & 371.78 & 41.35 & - & - \\
\hline $\begin{array}{l}\text { Upper epidermis } \\
\text { cells }\end{array}$ & 31.70 & 8.77 & 14.42 & 1.87 & 39.82 & 20.16 & 23.48 & 9.56 & 46.47 & 16.53 & 19.41 & 5.95 \\
\hline $\begin{array}{l}\text { Lower } \\
\text { epidermis cells }\end{array}$ & 20.90 & 5.15 & 12.60 & 1.41 & 31.90 & 15.30 & 18.25 & 3.69 & 29.96 & 6.69 & 11.16 & 3.73 \\
\hline Mesophyl layers & - & - & 169.41 & 20.84 & - & - & 171.55 & 16.12 & - & - & 195.40 & 4.67 \\
\hline $\begin{array}{l}\text { Palisade } \\
\text { parenchyma }\end{array}$ & 28.44 & 9.92 & 22.60 & 2.80 & 42.44 & 20.89 & 29.67 & 4.43 & 40.00 & 15.75 & 28.21 & 15.36 \\
\hline $\begin{array}{l}\text { Spongy } \\
\text { parenchyma }\end{array}$ & 39.50 & 16.76 & 18.98 & 2.00 & 32.33 & 9.15 & 20.72 & 3.47 & 27.31 & 17.07 & 18.16 & 6.53 \\
\hline
\end{tabular}

unicellular, conical-shaped, blunt tipped trichomes which are present sparsely on the outer surface (Fig. 3C). In contrast, long, non-glandular, unicellular, less number of sparsely arranged trichomes with a very pointed tip are found in B. napus (Fig. 3E). The epidermis is single layered with thick cuticle on the outside in all the three investigated species. The cuticle layer ranges from $5.36 \mu \mathrm{m}$ in B. napus to $7.77 \mu \mathrm{m}$ in B. juncea (Table 1). The epidermis is composed of compactly arranged square, rectangular, elliptical or circular cells. The epidermal layer (length) is found highest in $B$. 
rapa subsp. campestris $(36.22 \mu \mathrm{m})$ whereas it is lowest in B. napus $(23.75 \mu \mathrm{m})$ (Table 1). The epidermis contains anisocytic stomata. The epidermal layer is followed by a single layer of hypodermis, which is made up of collenchyma tissues except in B. juncea (Fig. 3D). The cortex layer consists of cortex parenchyma and endodermis. The cortex parenchyma is chlorenchymatic

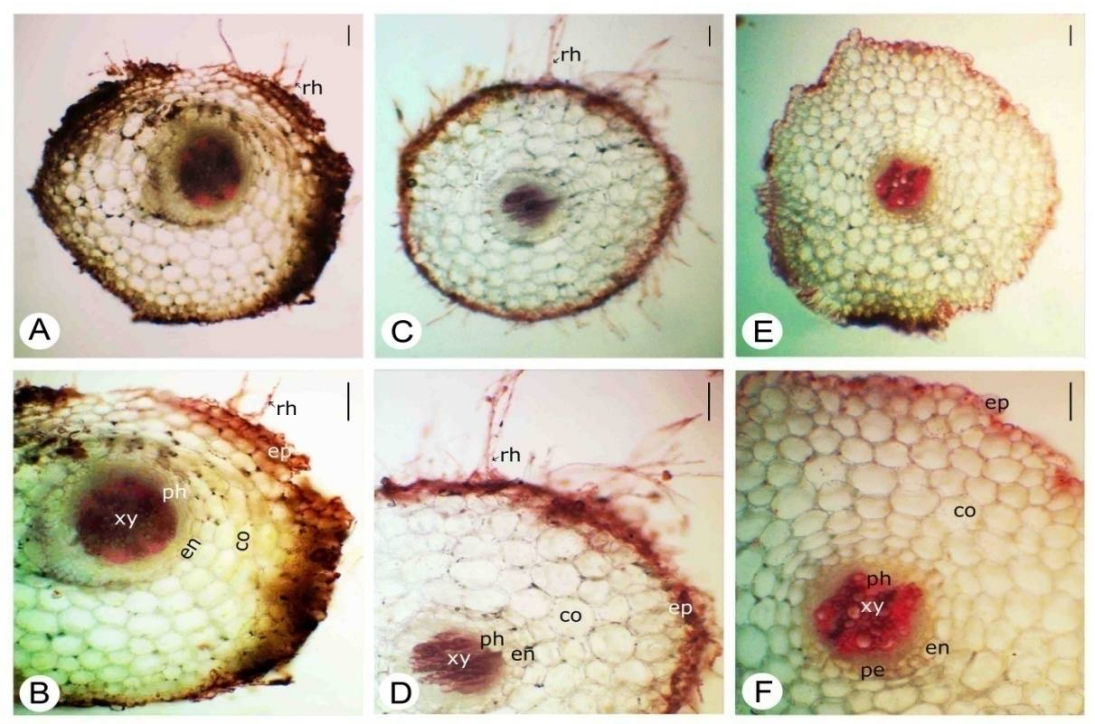

Fig. 2. Transverse section of root of three species of Brassica L. A-B. B. rapa subsp. campestris; C-D. B. juncea; E-F. B. napus; A, C, E: Full contour of root (4X); B, D, F: Detailed anatomical characters of root (10X). ep: epidermal cell, rh: root hair, co: cortex, en: endodermis, pe: pericycle, xy: xylem, ph: phloem. Bar $=100 \mu \mathrm{m}$.

Table 2. Young root anatomical characters of three species of Brassica $\mathrm{L}$.

\begin{tabular}{|c|c|c|c|c|c|c|c|}
\hline \multirow{2}{*}{ Taxa } & \multirow[t]{2}{*}{ Root hairs } & \multicolumn{2}{|c|}{ Cortex } & \multirow[t]{2}{*}{ Pericycle } & \multirow{2}{*}{$\begin{array}{l}\text { Xylem } \\
\text { Strand } \\
\end{array}$} & \multirow[t]{2}{*}{ Phloem } & \multirow[t]{2}{*}{ Pith } \\
\hline & & Parenchyma & Endodermis & & & & \\
\hline $\begin{array}{l}\text { B. rapa } \\
\text { subsp. } \\
\text { campestris }\end{array}$ & Present & 5-7 layered & 1 layered & 1 layered & Tertarch & 4-6 layered & Present \\
\hline B. juncea & Present & 4-5 layered & 1 layered & 1 layered & $\begin{array}{l}\text { Single } \\
\text { strand }\end{array}$ & 4-5 layered & Inconspicuous \\
\hline B. napus & Absent & 7-9 layered & 1 layered & 1 layered & Tetrarch & 4-5 layered & present \\
\hline
\end{tabular}

and is made up of 2-9 layers, thin-walled, with regular oval or circular cells. Cortex parenchyma also contains starch granules. The parenchymatous cells of $B$. rapa subsp. campestris and $B$. juncea contain more intense starch than B. napus (Fig. 3). Underneath the cortex parenchyma, there is a single layered rectangular or barrel shaped endodermis surrounding the vascular bundle of the stem. Pericycle is usually sclerenchymatic, 1-3 layered and surrounding the phloem layers of vascular bundles. The number of vascular bundles arranged in a ring varies from 7 to 25 in the studied species. 9 to 13 vascular bundles are found in B. rapa subsp. campestris whereas 7 to 12 and 17 to 25 vascular bundles are observed in B. juncea and B. napus, respectively (Table 3). Inter-fascicular region is located in between vascular bundles of $B$. rapa subsp. campestris and this region comprises sclerenchymatic cells while a continuous wavy band of multi-layered rectangular, sclerenchymatous conjunctive tissue is observed in B. juncea and B. napus. The type 
of vascular bundle is conjoint, collateral and open in B. juncea and B. napus (Figs. 3D \& 3F). The phloem is 2-7 layered and consists of irregular and squashed cells. The cambium is distinct and is located between phloem and xylem elements. The cells of cambium tissue are typically rectangular shaped and are arranged in 2-4 layers. Xylems of the vascular bundles are highly lignified. In B. rapa subsp. campestris, vascular bundles are found to be conjoint, collateral and closed (Figs. 3A-B and Table 3). The pith region located in the center of the stem is composed of large orbicular or polygonal parenchymatous cells and occupies much of the volume of stem in all the three studied species of Brassica (Figs. 3A, 3C \& 3E). A comparative account of stem anatomical characters among the three Brassica species has been depicted in Table 3. The highest numbers of vascular bundles are found in $B$. napus followed by $B$. rapa subsp. campestris, while the lowest number is noticed in $B$. juncea. It can easily be distinguished from other species by its round shaped stem, small, non-glandular, sparsely located unicellular, blunt-tipped trichomes. $B$. napus can be identified by its sparsely located unicellular, non-glandular, long trichomes with pointed tips (Table 3).

Table 3. Stem anatomical characters of three species of Brassica $\mathbf{L}$.

\begin{tabular}{|c|c|c|c|c|c|c|c|}
\hline \multirow[t]{2}{*}{ Taxa } & \multirow[t]{2}{*}{ Trichome } & \multicolumn{2}{|c|}{ Cortex } & \multirow[t]{2}{*}{ Pericycle } & \multirow{2}{*}{$\begin{array}{l}\text { Vascular bundle } \\
\text { Type }\end{array}$} & \multirow{2}{*}{$\begin{array}{l}\text { No. of } \\
\text { vascular } \\
\text { Bundles }\end{array}$} & \multirow[t]{2}{*}{ Phloem } \\
\hline & & Parenchyma & Endodermis & & & & \\
\hline $\begin{array}{l}\text { B. rapa } \\
\text { subsp. }\end{array}$ & Absent & 3-5 layered & 1 layered & 1 layered & Closed, Collateral & $9-13$ & 3-5 layered \\
\hline Campestris & & & & & & & \\
\hline B. juncea & Present & 2-4 layered & 1 layered & 1 layered & Open, Collateral & $7-12$ & 2-3 layered \\
\hline B. napus & Present & 6-9 layered & 1 layered & 2-3 layered & Open, Collateral & $17-25$ & 4-7 layered \\
\hline
\end{tabular}

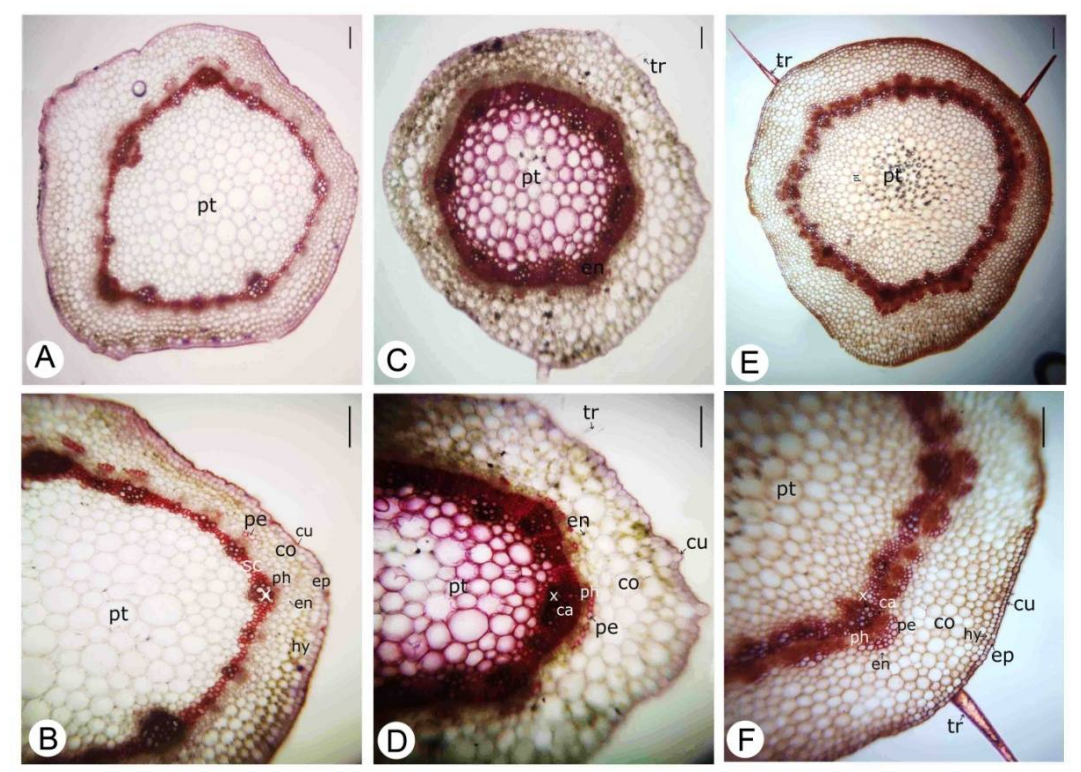

Fig. 3. Transverse section of stem of three species of Brassica L. A-B. B. rapa subsp. campestris; C-D. B. juncea; E-F. B. napus; A, C, E: Full contour of stem (4X); B, D, F: Detailed anatomical characters of stem (10X). cu: cuticle, ep: epidermis, co: cortex, hy: hypodermis, en: endodermis, pe: pericycle, sc: sclerenchyma, ph: phloem, ca: cambium, $\mathrm{x}$ : xylem, pt: pith, tr: trichome. Bar $=100 \mu \mathrm{m}$. 


\section{Leaf anatomy}

Transverse section of the dorsiventral leaves of the three species of Brassica provides diverse anatomical features in both leaf blade and midrib region. In the studied species, there is a single layer of epidermis observed on the adaxial and abaxial surface of the leaf. A thin layer of cuticle present on the upper and lower epidermis ranging from $3.06 \mu \mathrm{m}$ in $B$. juncea to $3.40 \mu \mathrm{m}$ in $B$. napus (Table 1). Epidermal cells of the both surfaces of lamina are rectangular to cubic in shape whereas the epidermal cells of midrib are ellipsoidal to oval in shape in all studied species. The laminar epidermal cells are much bigger than epidermal cells of midrib (Fig. 4). From the micromorphological observations of leaf epidermal surface, the epidermal cell walls are found irregular in shape and anticlinal cell wall are sinuate and undulating (Figs. 5A-5F, Table 5). The
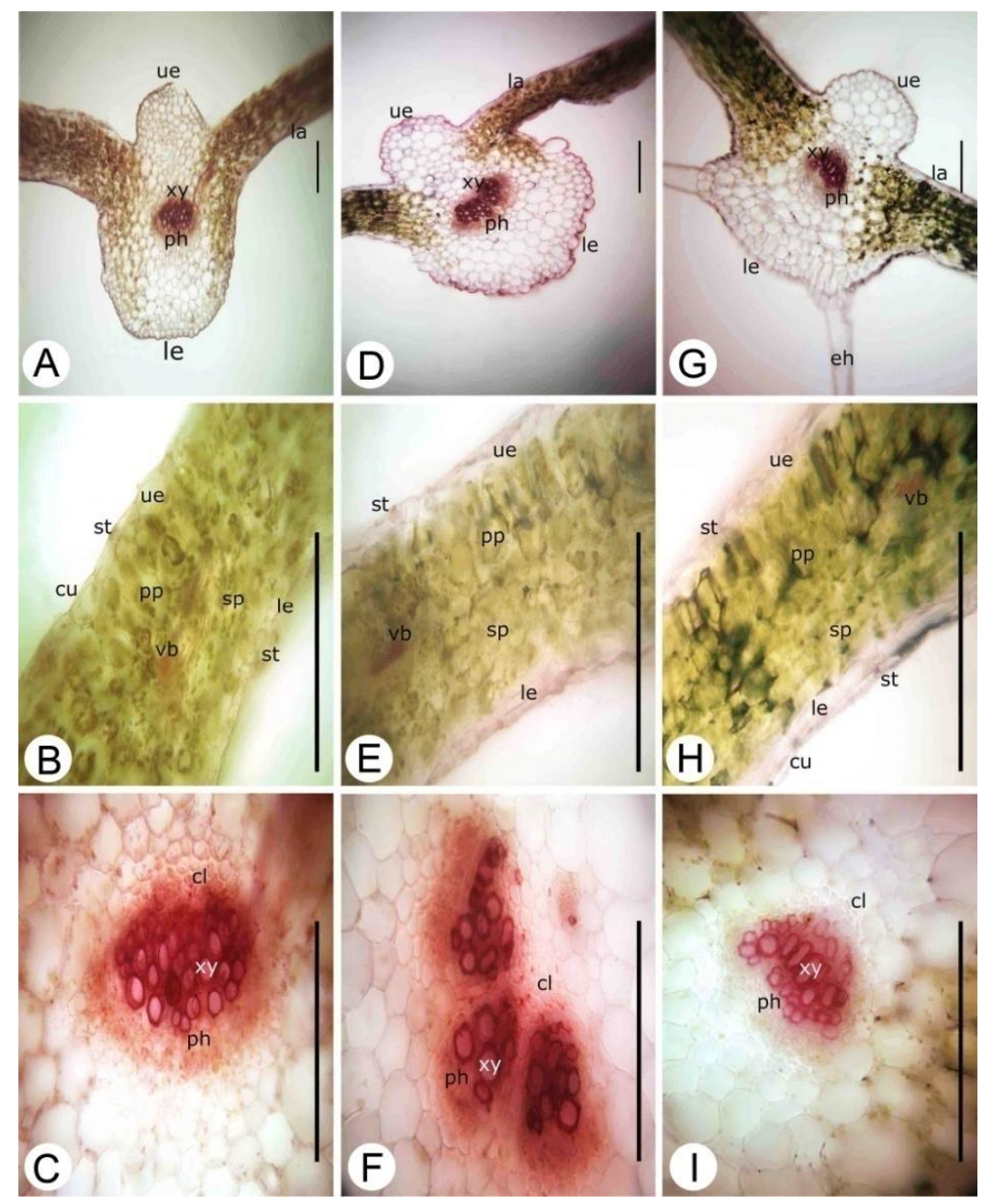

Fig. 4. Transverse section of leaf of Brassica L. species. A-C. B. rapa subsp. campestris; D-F. B. juncea; G-I. B. napus; A, D, G: Leaf section with lamina and midrib (10X); B, E, H: Detailed anatomical characters of lamina (40X); C, F, I: Detailed anatomical characters of midrib (40X); cu: cuticle, ue: upper epidermis, le: lower epidermis, eh: eglandular hair, vb: vascular bundle, st: stomata, cl: collenchymas, la: lamina, pp: palisade parenchyma, sp: spongy parenchyma, xy: xylem, ph: phloem. Bar $=100 \mu \mathrm{m}$. 
abaxial leaf surface of all the three species are covered with simple, non glandular, unicellular trichomes which are straight or curved, stalked, flattened in the lower part and tapering above, long on the midrib and veins, otherwise shorter with straight or hooked tips. Trichomes are densely present in B. rapa subsp. campestris and B. juncea, but sparsely found in B. napus (Figs. 5G-5I and Table 4). Amphistomatic types of stomata are observed on epidermal layers of all the studied species. Stomata are found to be elliptic in all species. Stomata are bigger in B. juncea $(24.47 \mu \mathrm{m})$, while they are smaller in $B$. rapa subsp. campestris $(19.34 \mu \mathrm{m})$ on both surfaces of leaves (Table 5). They may be either mesomorphic or higromorphic. The density of stomata is higher in abaxial surface (112.00-184.40) than the adaxial surface (69.28-105.20) in all the studied species (Table 5). Based on the arrangement of subsidiary cells that enclosing the guard cells, the stomata of the three studied species are anisocytic type (Figs. 5A-5F). The stomatal

Table 4. Comparative leaf anatomical characters of three species of Brassica $\mathrm{L}$.

\begin{tabular}{|c|c|c|c|c|c|c|}
\hline \multirow[t]{2}{*}{ Taxa } & \multirow[t]{2}{*}{ Trichomes } & \multirow{2}{*}{$\begin{array}{l}\text { Palisade } \\
\text { parenchyma }\end{array}$} & \multirow{2}{*}{$\begin{array}{l}\text { Spongy } \\
\text { parenchyma }\end{array}$} & \multirow[t]{2}{*}{ Midrib shape } & \multicolumn{2}{|c|}{ Middle vascular bundle } \\
\hline & & & & & $\begin{array}{l}\text { Collenchyma } \\
\text { on xylem }\end{array}$ & $\begin{array}{l}\text { Collenchyma } \\
\text { under phloem }\end{array}$ \\
\hline $\begin{array}{l}\text { B. rapa } \\
\text { subsp. } \\
\text { Campestris }\end{array}$ & $\begin{array}{l}\text { Densly } \\
\text { present }\end{array}$ & 2-3 layered & 3-5 layered & $\begin{array}{l}\text { Biconvex, adaxial less } \\
\text { angular, abaxial square } \\
\text { shaped with no ridges and } \\
\text { furrows }\end{array}$ & $1-2$ rows & 3 rows \\
\hline B. juncea & $\begin{array}{l}\text { Densely } \\
\text { present }\end{array}$ & 2-3 layered & 4-5 layered & $\begin{array}{l}\text { Biconvex, adaxial more } \\
\text { angular, semi-circular } \\
\text { abaxial with prominent } \\
\text { ridges and furrows }\end{array}$ & $4-5$ rows & 1-2 rows \\
\hline B. napus & $\begin{array}{l}\text { Sparsely } \\
\text { present }\end{array}$ & 3-5 layered & 4-5 layered & $\begin{array}{l}\text { Biconvex, adaxial angular, } \\
\text { abaxial semi-circular, } \\
\text { somewhat flattened with no } \\
\text { ridges and furrows }\end{array}$ & $3-5$ rows & $3-4$ rows \\
\hline
\end{tabular}

Table 5. Micro-morphological leaf epidermal surface characteristics of three species of Brassica $\mathrm{L}$.

\begin{tabular}{|c|c|c|c|c|c|c|}
\hline \multirow[t]{2}{*}{ Characters } & \multicolumn{2}{|c|}{ Brassica rapa subsp. campestri } & \multicolumn{2}{|c|}{ Brassica juncea } & \multicolumn{2}{|c|}{ Brassica napus } \\
\hline & Adaxial & Abaxial & Adaxial & Abaxial & Adaxial & Abaxial \\
\hline Anticlinal cell wall & Sinuate & Sinuate & Sinuate & Sinuate & Undulate & Undulate \\
\hline $\begin{array}{l}\text { Shape of epidermis } \\
\text { cells }\end{array}$ & Irregular & Irregular & Irregular & Irregular & Irregular & Irregular \\
\hline Stomata type & Anisocytic & Anisocytic & Anisocytic & Anisocytic & Anisocytic & Anisocytic \\
\hline Stomatal shape & Elliptical & Elliptical & Elliptical & Elliptical & Elliptical & Elliptical \\
\hline Stomata length $(\mu \mathrm{m})$ & $19.91 \pm 1.06$ & $19.34 \pm 1.90$ & $24.47 \pm 3.22$ & $24.47 \pm 0.51$ & $22.76 \pm 0.25$ & $24.12 \pm 2.20$ \\
\hline Stomata width $(\mu \mathrm{m})$ & $15.47 \pm 0.77$ & $15.62 \pm 0.44$ & $18.74 \pm 2.69$ & $20.02 \pm 1.68$ & $16.37 \pm 1.37$ & $19.74 \pm 0.45$ \\
\hline $\begin{array}{l}\text { Number of stomata } \\
\left(1 \mathrm{~mm}^{2}\right)\end{array}$ & $99.60 \pm 20.00$ & $146.00 \pm 14.03$ & $105.20 \pm 17.47$ & $184.40 \pm 9.50$ & $69.28 \pm 12.70$ & $112.00 \pm 14.89$ \\
\hline $\begin{array}{l}\text { Number of } \\
\text { epidermis cells }\end{array}$ & $349.00 \pm 22.19$ & $585.60 \pm 30.00$ & $315.60 \pm 24.50$ & $691.20 \pm 15.60$ & $349.00 \pm 21.00$ & $448.73 \pm 18.90$ \\
\hline Stomata index & 22.20 & 19.96 & 25.00 & 21.05 & 16.55 & 19.97 \\
\hline Stomata index ratio & 1.11 & 0.89 & 1.19 & 0.84 & 0.82 & 1.21 \\
\hline
\end{tabular}


index of the studied species ranges from 16.55-25.00 in the adaxial surface and 19.96-21.05 in the abaxial surface, while the stomatal index ratio for adaxial surface is between 0.82 (B. napus) and 1.19 (B. juncea), and for abaxial surface it is between 0.84 (B. juncea) and 1.21 (B. napus) (Table 5). In lamina, the mesophyll is bifacial (dorsiventral) in all species (Figs. 4B, 4E \& 4H). The mesophyll layer consists of palisade and spongy parenchyma cells, where in the palisade parenchyma cells are 2-5 layered and cylindrical to rectangular in shape. The longest palisade parenchymatous cell has been found in B. juncea $(42.44 \mu \mathrm{m})$ followed by B. napus $(40.00 \mu \mathrm{m})$, while the smallest palisade parenchyma is noted in B. rapa subsp. campestris $(28.44 \mu \mathrm{m})$ (Table 1). Spongy parenchyma cells are 3-5 layered, ellipsoidal or oval with no intercellular space. Vascular bundles are embedded in mesophyll and of the closed, collateral type, and are surrounded with a single layer of parenchymatous bundle sheath. Although the midrib is biconvex in all the examined species, each of them has some variations on either surface (Table 4, Figs. 4A, 4D \& 4G). In B. rapa subsp. campestris, adaxial surface is found to be less angular, whereas the abaxial surface is square with no ridges and furrows. $B$. juncea exhibits with more angular adaxial surface and semi-circular abaxial surface with prominent ridges and furrows. In B. napus, adaxial surface is angular whereas abaxial surface is semi-circled, somewhat flattened, with no ridges and furrows. Single, closed, collateral vascular bundle has been observed in the midrib of $B$. rapa subsp. campestris and B. napus. On the contrary, three discrete closed, collateral vascular bundles are present in the midrib of $B$. juncea. The xylems that present in the middle vascular bundles are more lignified. Subsequent collenchyma layers are found to present on the xylem and below the phloem tissues in the middle vascular bundles. No sclerenchymatic tissues are present on phloem layers of vascular bundle (Figs. 4C, 4F \& 4I).

The present study is probably the first as no micromorphology and anatomical investigation of Brassica in Bangladesh has been made earlier. Previously, several anatomical studies of various genera of the family Brassicaceae has been carried out to identify the members of Brassicaceae (Ančev and Goranova, 2006; Selvi and Paksoy, 2013; Tekin and Martin, 2017). The present study has revealed that stems of three studied Brassica species provide the general anatomical characteristics of the Cruciferae family (Fig. 3) which is in congruent with previous studies where the pith region has been found as parenchymatous and occupies a large proportion of the total diameter of the stem in the Cruciferae (Metcalfe and Chalk, 1957; Tekin and Martin, 2017). In a comparison of the results stem anatomy of Physoptychis haussknechtii Bornm., distributed mainly in Eurasia (Rešetnik et al., 2013), a member of Brassicaceae family (Tekin and Martin, 2017) and our results on examined Brassica species, showed the primary structure of stem which depicted with compactly arranged single layered epidermis covered with thick cuticle, followed by parenchymatous cortex layer, endodermis and sclerenchymatous pericycle. Beneath the pericycle, a continuous ring of sclerenchymatous cambium formed in between xylem and phloem elements of $B$. juncea and B. napus. The pith is formed from elliptical or circular parenchymatous cells in the center of stem. The results of our study shows that all the studied species of Brassica L. have similar anatomical properties as $P$. haussknechtii Bornm., such as having the stem of the primary structure, however the presence of cambium in $B$. juncea and $B$. napus have been found correspond with P. haussknechtii Bornm.

Metcalfe and Chalk (1957) stated that the stomata of Cruciferae family are of the cruciferous (anisocytic) type. The stomata of Brassica species were surrounded by three subsidiary cells of which one is usually much smaller than the other two, the so-called Cruciferous (Anisocytic) type (Figs. 5A-5F). However, occurrence of such type of stomata is reported to be common in other genera, namely Ricotia L. and Chrysochamela (Fenzl) Boiss. of the same family by many workers (Selvi and Paksoy, 2013; Çakilcioğlu et al., 2017). Due to the presence of same type of stomata in 
different genera of the same family, this feature may be helpful in delimitation of ranking in taxonomic studies (Santos et al., 2018).

Ančev and Goranova (2006) studied trichome morphology of eleven genera of tribe Alysseae of Brassicaceae and recognized four types, viz. simple, stalked 2 to 5 armed, stellate and dendritic trichomes. In the present study, trichomes found in leaf in all the studied species are simple, straight, stalked, flattened in the lower part, tapering above, long on the midrib and veins, otherwise shorter with straight or hooked tips (Figs. 5G-5I). According to Ančev and Goranova (2006), simple trichomes cover the leaves of Lunaria rediviva L. and mixed with stalked 2 to 3armed ones, compose the leaf indumentums of Camelina sativa. Simple trichomes on the silicules of Clypeola jonthlaspi subsp. microcarpa are columnar with transverse furrows. The stem trichomes of Brassica juncea are simple, short, unicellular, conical-shaped and blunt at the tip, while it has been found long and tapering above in the stem of $B$. napus and no trichome been found in B. rapa subsp. campestris. Trichomes basically serve as defense tissue and provide worthy anatomical features to characterize species (Shethi et al., 2019). Therefore, it may be considered that the size and shape and presence or absence of trichomes may provide information to recognize the species of Brassica genus.

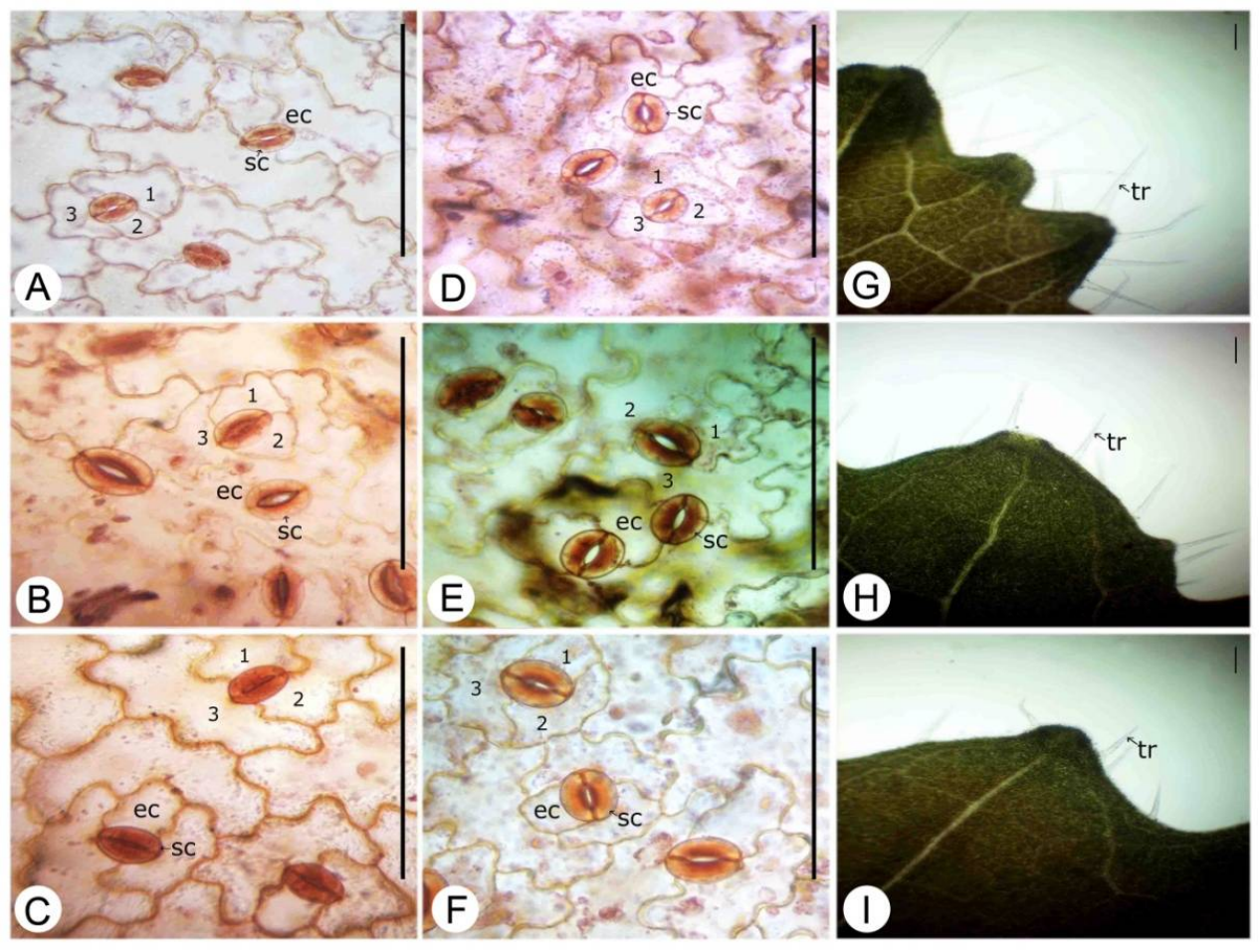

Fig. 5. Stomata of adaxial surface (A, B, C) (40X) and abaxial surface (D, E, F) (40X) and trichomes (G, H, I) (4X) of Brassica L. species. A, D, G. B. rapa subsp. campestris; B, E, H. B. juncea; C, F, I. B. napus. sc: stoma cell, ec: epidermal cell, tr: trichome. Bar $=100 \mu \mathrm{m}$.

Results revealed form the present investigation on three Brassica species are discussed with previous studies on some other genera, i.e. Ricotia L. (Selvi and Paksoy, 2013) and Chrysochamela (Fenzl) Boiss. (Çakilcioğlu et al., 2017) of the same family. In the leaf anatomy of our present studied species showed quite similarities with the species of Ricotia L. and 
Chrysochamela (Fenzl) Boiss., viz. the epidermis of midrib and lamina is uniseriate and covered with thin cuticle, mesophyll is bifacial, spongy parenchyma is well developed with oval to circular cells with no intercellular space, and palisade parenchyma composed of cylindrical cells. Stomata are comparatively tiny and amphistomatic. In Chrysochamela (Fenzl) Boiss., the lower and upper epidermal cells of the middle vascular bundle are bigger than epidermal cells in the mesophyll layer (Çakilcioğlu et al., 2017). However, in the studied Brassica species, the laminar epidermal cells are much bigger than the upper and lower epidermal cells of midrib. In the midrib, collateral type of vascular bundle (closed collateral) has been found in all the examined species of Brassica L.

According to Pandey (1978), number of xylem strands in the vascular bundle of root, is specific to species. As the studied species are found with tetrarch xylem (except, B. juncea which found with single strand xylem in the center) in root, it may be considered as an important character for distinguishing Brassica species. In our study, primary root structure has been found in three Brassica species. However, secondary root structure in some other genera of Brassicaceae has been noticed in previous studies (Orcan and Binzet, 2003; Tekin and Martin, 2017).

The present study on anatomical profiles of three Brassica species from Bangladesh is the first of its nature. Besides, other anatomical traits, viz. primary structure and tetrarch or single strand exarch xylem in root, size, shape and presence or absence of trichomes over stem, midrib shape of leaf are considered as distinctive characters for delimitation of the Brassica species investigated. Inclusion of additional species employing additional tools would throw more light on better understanding of species delimitation and interspecific relationships of the genus Brassica.

\section{Acknowledgment}

The authors are thankful to Bangladesh Agricultural Research Institute (BARI), Bangladesh Institute of Nuclear Agriculture (BINA) for providing the seeds of three species of Brassica used in this study.

\section{References}

Ahmed, Z.U., Hassan, M.A., Begum, Z.N.T., Khondker, M., Kabir, S.M.H., Ahmad, M., Ahmed, A.T.A., Rahman, A.K.A. and Haque, E.U. (Eds). 2008. Encyclopedia of Flora and Fauna of Bangladesh, Vol. 7. Angiosperm: Dicotyledons (Balsaminaceae - Euphorbiaceae). Asiatic Society of Bangladesh, Dhaka. pp. 52-75.

Ančev, M. and Goranova, V. 2006. Trichome morphology of eleven genera of the tribe Alysseae (Brassicaceae) occurring in Bulgaria. Willdenowia 36: 193-204.

Bayirli, M., Selvi, S. and Çakilcioglu, U. 2014. Determining different plant leaves' fractal dimensions: A new approach to taxonomical study of plants. Bangladesh J. Bot. 43(3): 267-275.

Çakilcioğlu, U., Paksoy, M.Y., Babacan, E. and Polat, R. 2017. Comparative micromorphology and anatomy of Chrysochamela (Fenzl) Boiss. (Cruciferae) growing in Turkey. Bangladesh J. Bot. 46(2): 549-558.

Dilcher, D. 1974. Approaches to the identification of angiosperm leaf remains. The Bot. Rev. 40(1): 3-157.

Gupta, S.K. and Pratap, A. 2007. History, origin and evolution. Adv. Bot. Res. 45: 2-20.

Hayta, S., Taşar, N., Çakilcioğlu, U. and Gedik, O. 2014. Morphological, karyological features and pollen morphology of endemic Ebenus haussknechtii Bornm. ex Hub.-Mor. from Turkey; A traditional medicinal herb. J. Herbal Med. 4: 141-146.

Hedge, I.C. 1976. A systematic and geographical survey of old World Cruciferae. In: Vaughan, J.G., Macleod, A.J. and Jones, B.M.G. (Eds), The Biology and Chemistry of the Cruciferae, London, pp. $1-46$.

Jahan, N., Bhuiyan, S.R., Talukder, M.Z.A., Alam, M.A. and Parvin, M. 2013. Genetic diversity analysis in Brassica rapa using morphological characters. Bangladesh J. Agri. Res. 38(1): 11-18. 
Kasem, W.T., Ghareeb, A. and Marwa, E. 2011. Seed morphology and seed coat sculpturing of 32 taxa of family Brassicaceae. J. Am. Sci. 7(2): 166-178.

Kaya, A. and Dirmenci, T. 2012. Nutlet morphology of Turkish Ziziphora L. (Lamiaceae). Plant Biosystems 146(3): 560-563.

Khatun, S., Çakilcioğlu, U. and Chatterjee, N.C. 2011. Pharmacognostic value of leaf anatomy and trichome morphology for identification of forskolin in a novel medicinal plant Coleus forskohlii Briq. Biological Diversity \& Conservation 4: 165-171.

Meidner, H. and Mansfield, T.A. 1968. Physiology of Stomata. McGraw-Hill, New York, U.S.A., 179 pp.

Metcalfe, C.R. and Chalk, L. 1957. Anatomy of the Dicotyledons (Leaves, stem and wood in relation to taxonomy with notes on economic uses). Vol. 1.Oxford University Press, Amen House, London, pp. 7987.

Orcan, N. and Binzet, R. 2003. The anatomical and palinological properties of Alyssum obtusifolium Steven ex DC. (Brassicaceae). Turkish J. Bot. 27: 63-68.

Pandey, B.P. 1978. Plant Anatomy. S. Chand and Co. Ltd. Ramnagar, New Delhi, India, pp. 232-233.

Razzaque, M. and Karim, M. 2007. Effect of varying concentrations of certain salts on germination and seedling vigor of two rape (Bassica napus L.) varieties. Mesopotamia J. Agric. 14(2): 25-40.

Rešetnik, I., Šatović, Z., Schneeweiss, G.M. and Liber, Z. 2013. Phylogenetic relationships in Brassicaceae tribe Alysseae inferred from nuclear ribosomal and chloroplast DNA sequence data. Molecular Phylogenetics and Evolution 69: 772-786.

Saha, S., Molla, M.R., Chandra, D. and Rahman, L. 2008. Assessment of genetic variation and relationships within the varieties of four Brassica species by RAPD markers. Aus. J. Crop Sci. 2(3): 105-114.

Santos, V.L.P., Raman, V., Bobekc, V.B., Migaczc, I.P., Franco, C.R.C., Khan, I.K. and Bude, J.M. 2018. Anatomy and microscopy of Piper caldense, a folk medicinal plant from Brazil. Rev. Bras. Farmacogn. 28: 9-15.

Satil, F., Aslan, M., Erdogan, E., Polat, R. and Selvi, S. 2015. Comparative anatomical studies on some species of Hyoscyamus L. (Solanaceae) growing in Turkey. Bangladesh J. Bot. 44(1): 37-43.

Selvi, S. and Paksoy, M.Y. 2013. Comparative anatomy of stem and leaf of Ricotia L. growing in Turkey. Bangladesh J. Bot. 42(1): 123-130.

Selvi, S., Paksoy, M.Y., Polat, R. and Çakilcioğlu, U. 2014. Micromorphological and anatomical characteristics of the genus Chrysophthalmum schultz Bip. (Asteraceae) growing in Turkey. Proc. Nat. Acad. Sci. India Section B: Biological Sciences 84: 431-438.

Shethi, K.J., Begum, M. and Rashid, P. 2017. Comparative anatomy of Momordica dioica Roxb. ex Willd. and M. cochinchinensis (Lour.) Spreng. Bangladesh J. Bot. 46(2): 725-732.

Shethi, K.J., Rashid, P., Begum, M. and Rahman, M.O. 2019. Morphoanatomical profile of five species of Piper L. from Bangladesh and its taxonomic significance. Bangladesh J. Plant Taxon. 26(1): 57-68.

Tekin, M. and Martin, E. 2017. Morphology, anatomy and karyology of endangered Turkish endemic Physoptychis haussknechtii Bornm. (Brassicaceae) from Central Anatolia. Acta Bot. Croat. 76(1): 3240.

Theobald, W.L., Krahulik, J.L. and Rollins, R.C. 1979. Trichome description and classification. In: Metcalfe, C.R. and Chalk, L. (Eds), Anatomy of the dicotyledons. Vol. 1. Oxford University Press, Amen House, Oxford, London, pp. 40-53.

Warwick, S.I., Francis, A. and Al-Shehbaz, I.A. 2006. Brassicaceae: Species checklist and database on CDRom. Pl. Syst. Evol. 259: 249-258.

Wilkinson, H.P. 1979. The Plant Surface (Mainly Leaf). In: Metcalfe, C.R. and Chalk, L. (Eds), Anatomy of the Dicotyledons. Vol. 1. Clarendon Press, Oxford, U.K., pp. 97-165. 